Mari Hatavara, Sari Kivistö ja Saija Isomaa

Kirjallisuustiede, Tampereen yliopisto

\title{
Monitieteistä tekstianalyysia, teoreettista kunnianhimoa, uusia tutkimussuuntauksia
}

Tampereen yliopiston kirjallisuudentutkimuksen historia alkaa vuodesta 1950, jolloin Unto Kupiaisesta tehtiin silloisen Yhteiskunnallisen korkeakoulun kirjallisuudenhistorian professori. Huumorista väitellyt Kupiainen suhtautui varauksellisesti oppilaitoksen siirtämiseen pääkaupungista Tampereelle, sillä kalliinpaikan lisä laski yhdellä pykälällä, vaikka kirjat ja viski maksoivat Tampereella yhtä paljon kuin Helsingissäkin. Myös oppilaitoksen ripeä kasvu huoletti Kupiaista, sillä vaarana oli, että ”Tampereellekin muodostettaisiin Suomen vesipöhöinen kulttuuripää”. Huoli osoittautui sentään turhaksi. Kupiaisen tekemistä piscinomi-kasteista eli kalastusnimien antamisesta opiskelijoille on aikoja sitten luovuttu, mutta tamperelaiset kirjallisuustieteilijät kokoontuvat yhä edelleen toukokuiseen Kupiais-juhlaan, jossa Unto ja Kerttu Kupiaisen rahastosta jaetaan gradupalkinto kahdelle erinomaiselle kirjallisuustieteen gradulle.

Kirjallisuustiede on Tampereella perinteisesti jakautunut Suomen kirjallisuuteen ja yleiseen kirjallisuustieteeseen, jota on vuodesta 2012 tarjottu kertomus- ja tekstiteoriaan painottuneesti. Opiskelija suorittaa kirjallisuustieteen tutkinto-ohjelmassa kirjallisuustieteen kandidaattiohjelman ja suuntautuu toiseen maisteriohjelmaan. Kertomus- ja tekstiteorian maisteriopinnoissa painotetaan kansainvälisen kertomusteorian nykysuuntia, jotka tarjoavat metodeja useille tekstejä tutkiville aloille. Suomen kirjallisuuden maisteriopinnoissa syvennytään opiskelijan tutkimuksellisen kiinnostuksen mukaan kirjallisuustieteen eri osa-alueisiin: kirjallisuudentutkimuksen teorioihin, tekstianalyyttisiin metodeihin sekä kirjallisuuden ilmiöihin. Jatko-opinnot suoritetaan kirjallisuustieteen tohtoriohjelmassa.

Tutkinto-ohjelmassa on vahvaa historiallisten jatkumojen, uusimman kansainvälisen tutkimuskentän ja monitieteisen kirjallisuudentutkimuksen osaamista. Keskeisiin alueisiin kuuluvat kertomuksen teoria, lajiteoria, satiirin tutkimus, kirjallisuushistorian ja -instituution tutkimus, ekokritiikki, lasten- ja nuortenkirjallisuuden tutkimus ja kuvan ja sanan sekä sarjakuvan tutkimus, mutta myös posthumanismi, tekstienvälisyys, ekonomiakritiikki sekä huumorin ja tunteiden tutkimus tarjoavat lähtökohtia tutkimukselle. Monet tutkimuksista tarkastelevat nykykirjallisuutta, mutta yhtä lailla tutkitaan vanhempaa kirjallisuutta ja kirjallisuuden klassikoita erilaisista teoreettisista, kontekstualisoivista ja kansainvälisesti vertailevista näkökulmista. Samalla luodaan temaattisia ja metodisia yhteyksiä muihin tieteenaloihin, kuten kieli-, kulttuuri- ja 
yhteiskuntatieteisiin. Vahvoina periaatteina kulkevat monitieteinen yhteistyö sekä yleisempi tiedepoliittinen ja yhteiskunnallinen osallistuvuus.

Kirjallisuustieteen tutkinto-ohjelma koordinoi yliopiston monitieteistä kertomuksen tutkimuksen keskusta Narrare. Keskus toimii tutkimusympäristönä eri tieteenaloilta tuleville tutkijoille yhteistyössä alan johtavien kansainvälisten tutkimuskeskusten samoin kuin ei-akateemisten yhteisöjen kanssa. Kirjallisuustieteen tutkinto-ohjelman yhteydessä toimii useita tutkimushankkeita, joista kaksi on Suomen Akatemian rahoittamia. Professori Mari Hatavaran johtama Jyväskylän, Helsingin ja Tampereen yliopiston konsortiohanke LILI: The Literary in Life: Exploring the Boundaries between Literature and the Everyday (2015-2019) tutkii monimetodisesti kirjallisuuden ja sosiaalisen elämän suhdetta. Dosentti Maria Mäkelä työskentelee tutkijatohtorin projektissaan Voice as Experience: Life-Storying in Contemporary Media (2014-2018). Lisäksi on säätiöiden rahoituksella toimivia hankkeita. Dosentti Saija Isomaan johtama Koneen säätiön tutkimushanke Synkistyvät tulevaisuudenkuvat: Dystooppinen fiktio nykykirjallisuudessa (2015-2019) keskittyy kotimaiseen nykydystopiaan. Professori Sari Kivistö vetää Helsingin Sanomain Säätiön hanketta Painovapaus ja pilkkakuvasto (2016-2017), joka kartoittaa pila- ja pilkkakuvaston kehitystä Suomessa osana eurooppalaisia suuntauksia.

Projektien tutkijat ja tutkimustoiminta vaikuttavat aktiivisesti paitsi tutkijoiden julkaisuihin ja seminaarien ja konferenssien aiheisiin myös opetukseen. Opetuksessa pyritäänkin tuomaan uusin tutkimustieto välittömästi opiskelijoiden ulottuville ja kannustetaan tutkivaan oppimiseen. Opiskelijat ja jatko-opiskelijat työstävät tutkielmia esimerkiksi posthumanismista, fanifiktiosta, keskiajan narratologiasta, fantasian kulttuurisesta merkityksestä, apokalyptisestä kerronnasta, blogiteksteistä ja sarjakuvasta. Tutkinto-ohjelma järjestää useita vuosittaisia laajemmalle yleisölle tarkoitettuja seminaareja ja esitelmätilaisuuksia yhteistyössä muun muassa Radio Moreenin, Työväenmuseo Werstaan ja Tampereen kaupunginkirjaston kanssa. Kirjallisuustieteen tutkijat toimivat luottamustehtävissä kansallisissa ja kansainvälisissä kirjallisuudentutkimuksen instituutioissa, yhdistyksissä, seuroissa ja verkostoissa.

Tamperelaiset kirjallisuudenopiskelijat ovat järjestyneet ainejärjestöönsä Teema ry. Teema jakaa vuosittain Tiiliskivi-palkinnon - Finlaysonin seinästä periytyvän, painavaa teossisältöä symboloivan tiilen - mediassa liian vähälle huomiolle jääneelle teokselle. Opiskelijat perustivat äskettäin oman kirjallisuudentutkimuksen lehden Metalepsis, jossa julkaistaan opiskelijoiden artikkeleita.

Tampereen yliopistolla on tätä kirjoitettaessa meneillään organisaatiomuutos, jossa valmistaudutaan tamperelaiset yliopistot yhdistävän Tampere3-yliopiston perustamiseen vuonna 2019. Prosessi tuo muutoksia kirjallisuustieteen kandidaattiohjelman tieteenalakirjoon ja vaikuttaa maisteriohjelmien organisoitumiseen. Muutokset vahvistavat ja monialaistavat tutkimusta ja opetusta. 